Journal of Finance and Accounting

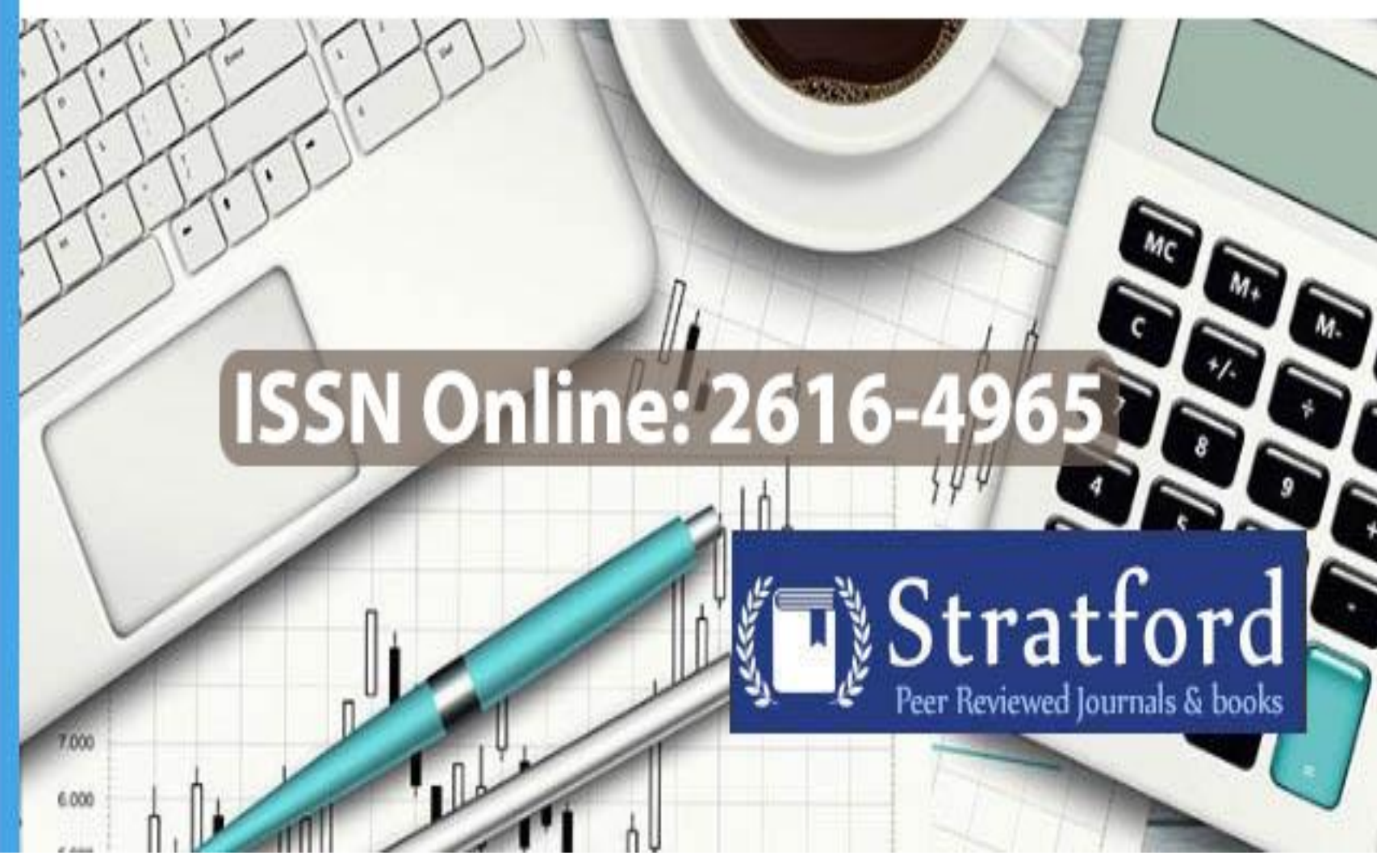

Financial Risks and Its Effect on Financial Performance of Investment Firms Listed at the Nairobi Securities Exchange in Kenya

Caroline Wanjira Gacheru 


\title{
Financial Risks and Its Effect on Financial Performance of Investment Firms Listed at the Nairobi Securities Exchange in Kenya
}

\author{
Caroline Wanjira Gacheru \\ Postgraduate Student, The Catholic University of Eastern Africa \\ Email of the corresponding author: carolgacheru019@gmail.com
}

How to cite this article: Gacheru C., W. (2021). Financial Risks and Its Effect on Financial Performance of Investment Firms Listed at the Nairobi Securities Exchange in Kenya. Journal of Finance and Accounting. Vol 5(2) pp. 86-102 https://doi.org/10.53819/81018102t2005

\section{Abstract}

The study investigated financial risks and its effect on the financial performance of investment firms listed at NSE. The study was guided by three research objectives; to determine the influence of foreign exchange risk, liquidity risk, and interest rate risks on the financial performance of investment firms listed at the NSE. The study used secondary data for the period, 2011-2018. The study employed a descriptive research design. The target population was the four investment companies listed on the NSE. Secondary data was collected from the financial annual reports of the firms. Statistical Packages for Social Sciences (SPSS) version 20.0 was used for data analysis. Descriptive statistics, regression analysis, and diagnostic tests were employed. The study concludes that a decrease in liquidity risk results to increased financial performance. A decrease in foreign exchange risk exposure could lead to improved financial performance. The study concludes that interest rate risk was negatively and significantly related to financial performance. Further, the study concludes that firm size had a positive and significant relationship with financial performance. The study recommends that the listed investment firms should increase the current ratio to minimize exposure to financial risks and the firms should also ensure they invest the idle cash to diversify investment portfolio. The study recommends that the management of investment firms should introduce a robust efficient and effective strategies that can assess, identify, and manage foreign exchange risks. Investment firms can also use various financial derivatives to reduce the effect of exchange rate risk. The study recommends that the firms can explore means they can use to improve capacities to manage interest rate risks exposure. For instance, interest rate risks can be mitigated by using financial derivatives and also through securitization of assets to minimize interest rate risks.

Keywords: Financial Risks, Financial Performance, Liquidity Risk, Interest Rate Risks, Foreign Exchange Risk. 


\subsection{Introduction}

Every finance decision is associated with risk. Therefore, the way investment firms manage risk associated with finances is significant to their overall financial performance (Cuong, 2019). The hypothetical belief is that financial risks result into financial performance' failure as long it is not properly managed. In a rejoinder, Arif and Showket (2019) indicate that financial risks and performance should be assessed interdependently because they may result to closure of investment firms or lead to sustainability. According to Wani and Ahmed (2018), when firms have financial risks exposure, there is a possibility of loss but also an opportunity to make profit. The fact that financial risk is a subcategory of a firm's risks, one of the main objectives of a firm is to lower cash flows and volatility of earnings because of exposure to financial risks. The reduction mechanisms permit the affected firm to perform better forecast (Patarai \& Mohamad, 2016). Moreover, this will help in ensuring sufficiency of funds for investments.

Financial risk has been defined as a firm's inability to meet unexpected and anticipated cash demand through cash flows generated. Simply put, it is risk at which a firm lacks adequate cash to utilize for its own obligation (James \& Kepha, 2020). The financial risks may include liquidity risk, technical provision risk, reinsurance risk, interest rate risks, foreign exchange risks, credit risk, underwriting risk, solvency risk among others.

Liquidity risk is when a firm is unable to meet its short-term financial demands when required to. Liquidity can be measured using current ratio and quick ratio (Mamatzakis \& Bermpei, 2017). Further, credit risk is the current and prospective risk to earning and capital resulting from failure by an obligor to meet the terms of the contract and can be measured by non-performing loans that are usually experienced by every financial institution. On the other hand, underwriting risk occurs when the incurred cost to cover a claim exceeds premium paid in total and can be measured using ratio of claims or loss incurred to premium earned (Mirie, 2018).

Interest rate risk occurs as a result of fluctuation of rates of interest which then affect firm liabilities and its financial assets directly (Matayo \& Muturi, 2018) and can be measured by the net foreign currency exposure relative to its net total assets. Meanwhile, solvency risk can be measured using ratio of total liabilities to total assets while reinsurance risk can be measured by utilization of ratio of premium ceded to total assets (Sisay, 2017).

Financial performance can be defined as the ability of a firm to achieve internal and external objectives or the level by which a firm's financial goals are met (Wang \& Sarkis, 2017). Financial performance can be measured using various operational indicators. According to Le, Shan, and Taylor (2020), the main financial performance measures are; the return on equity (ROE), return on assets (ROA), leverage, liquidity, firm size, and Tobin's Q among others.

\subsection{Statement of the Problem}

Investment firms in Kenya are susceptible to financial risks arising from the micro and macroenvironment. The financial sustainability of the investment as well as their long-term financial viability are threatened by these risks (Mwanja, Evusa, \& Ndirangu, 2018). Despite the provided guidelines to guide investment firms to manage financial risks and improve their performance, some firms have experienced financial risks challenges such as declined good reputation due to collapse of some brokerage firms, lack of well-trained professionals who can offer prompt advice on financial risks, high liquidity problems, among others. Such concerns only lead to decline in 
financial performance of these firms. Further, NSE (2018) reported a decline trend in the investment firms' performance (ROE). The report showed that the average ROE of the investment firms stood at $2.8 \%$ as at 2012, which declined to $1.0 \%$ in 2013 thereby an indication of decrease in financial performance.

Several studies have been conducted on financial risks and performance. For instance, Arif and Showket (2019) did a study on the effect of financial risks on firm performance of banks in Turkey and found that liquidity risk, solvency risk, and firm size had a positive significant relationship with financial performance. Underwriting risk had no significant relationship. Eneyew (2020) study on relationship between financial risks and performance of service firms found that credit and liquidity risks had insignificant negative relationship with profitability while foreign exchange and interest rate risks had an insignificant positive relationship. Sisay (2017) study established that financial risks including foreign exchange, operation risk had a significant positive effect on financial performance of manufacturing industries (leverage and firm size) of insurance firms while credit and liquidity insignificant positive relationship with performance. Chipa and Wamiori (2020) study found that the liquidity risk, operation risk had a positive statistical effect on financial performance (ROA) of insurance firms while credit risk and interest rate risk had negative significant effect on performance. Muinde (2018) found that liquidity and underwriting risks had a positive significant relationship with banks' financial performance (firm size and ROA). The relationship between credit risk and performance was negatively insignificant.

As shown above, past studies on financial risk and financial performance have indicated somewhat conflicting findings, others agreeing that financial risks had significant or insignificant positive relationship with performance while others found negative significant or insignificant relationship. Thus, the contradicting results calls for further research. Further, most studies done in Kenya focused on other sectors making it difficult to draw inferences and henceforth the need for the current study that focusses on investment firms listed at NSE. In addition, some studies were done in developed countries hence their findings cannot be used to contextualize and generalize the local case. Based on such glaring gaps, the current study sought to add knowledge on the study area so as to provide an explanation to the question, what is the influence of financial risks on the financial performance of investment firms listed at NSE?

\subsection{Specific Objectives}

i. To establish the influence of liquidity risk on the financial performance of investment firms listed at the NSE.

ii. To examine the influence of interest rate risks on the financial performance of investment firms listed at the NSE.

iii. To determine the influence of foreign exchange risk on the financial performance of investment firms listed at the NSE.

\subsection{The Conceptual Framework}

A conceptual shows the relationship between variables chosen by a study. Figure 1 shows the relationship between the variables. 
Figure 1: The Conceptual Framework

\section{Independent variables}

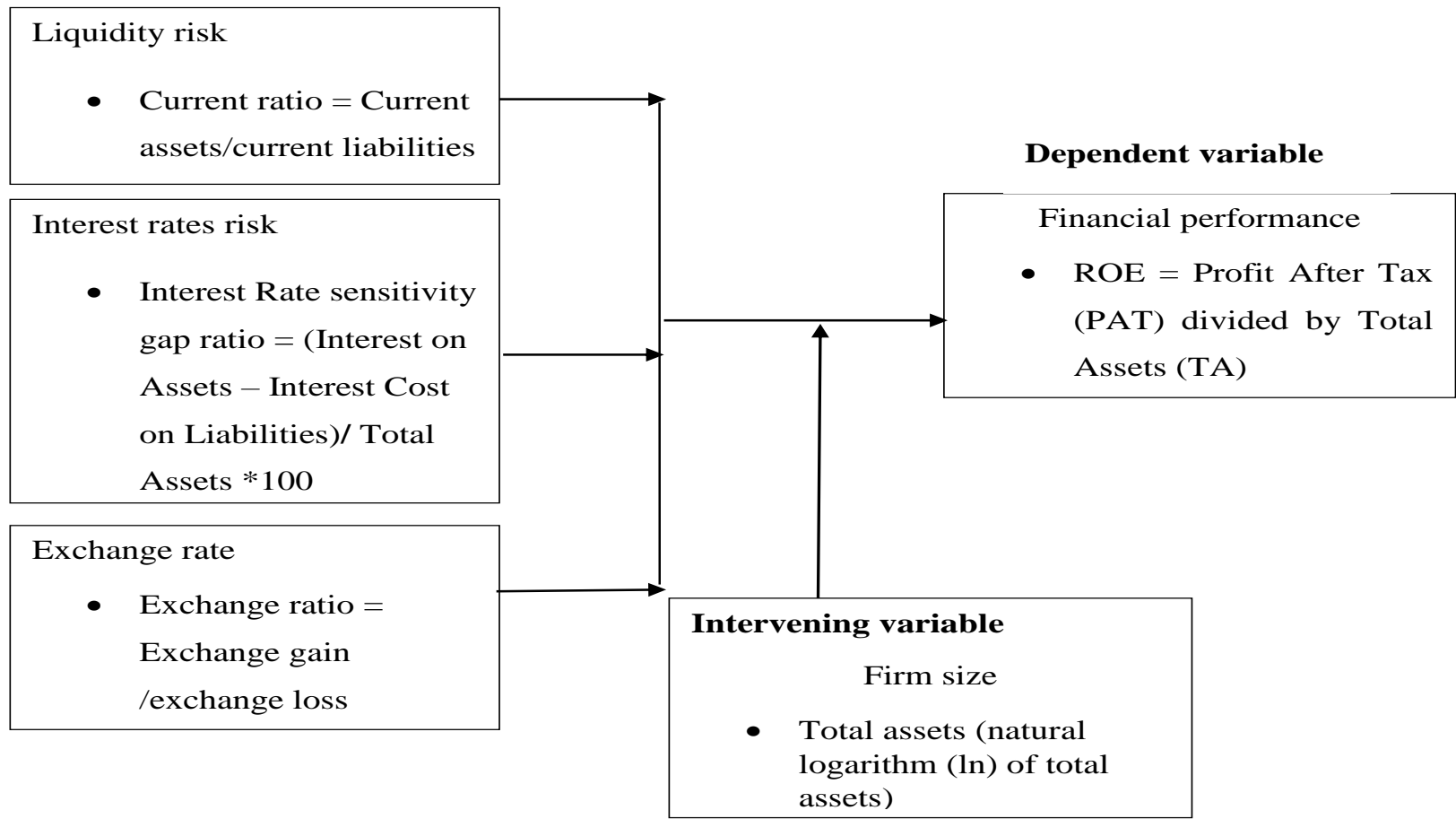

\subsection{Literature Review}

\subsection{Theoretical Framework}

\subsubsection{The Liquidity Preference Theory}

The theory was introduced by Keynes in 1936. The theory states that when firms deal with longterm maturities' securities, investors always demand higher rates of interest. Basically, such action often tends to be riskier because with all other factors' constant, firm investors opt for highly liquid holdings or cash (Lavoie \& Reissl, 2019). Based on this theory, rate of interest on short-term securities tends to be low due to the fact that firm investors buy assets on long or medium-term securities thereby sacrificing less liquidity. The assumption of the theory is that highly liquid investments in the firm are easier to be sold for full value.

In relation to its relevance to the current study, the theory attempts to explain the rationale for holding assets by investors. Investors will often go for highly liquid assets as they also avoid investment firms with high liquidity risk, they do this by stashing up their cash in the highly liquid investment firms thereby exposing the highly liquidity risky firms to financial risks vis-à-vis poor financial performance. Therefore, the intention of investors to go for highly liquid as indicated by the theory can expose firms to risk and eventually declined performance. 


\subsubsection{Agency Theory}

The agency theory was put forth by Jensen and Meckling in 1976. The theory is premised on contractual relations between two parties (agents and the principal) who have different roles to perform. The theory consists of delegation of decision-making authority by the principal to the agent (Jensen \& Meckling, 1976). Additionally, the firm agent is mandated with powers that brings the principal into a contractual relationship with the third party without necessarilymaking reference to the third party. Agency theory argues that there exists a mismatch that arises from the asymmetric information between management, debt holders, and shareholders regarding the distribution of earnings which can result into firms getting engaged in more risk averse profile projects or failure to engage in net profit projects that have positive outcome (Panda \& Leepsa, 2017).

According to the theory, mismatch in agency issues have been proven to influence attitudes by managers toward risk taking and hedging in the field of investments. The relevance of the theory to the current research is based on the fact that it informs the firm structure or firm governance variable and risk affinity thus it plays essential role in credit risk management decision-making to improve the overall financial performance. Therefore, the absence of push and pull between the agents and the principal can lead to increased financial performance and vice versa.

\subsection{Empirical Reviews}

\subsubsection{Financial Risks and Financial Performance}

Globally, Wani and Ahmad (2018) researched on the relationship between financial risk and financial performance of insurance firms in India. The sample size was 8 life insurance firms. Secondary data on the predictor variables (liquidity risk, capital management risk, solvency risk, firm size and underwriting risk) was gathered. The study found that solvency risk, liquidity risk, capital management risk and firm size had a negative significant relationship with financial performance. Cuong (2019) study was based assessing the effect of financial risk as a measure of liquidity risk on the European banks' financial performance. The study used a sample size comprising of a panel of the EU banks for the period of 2001-2011. The study found that there was a significant and negative effect of liquidity risk on the financial performance. Another study by Patarai and Mohamad (2016) assessed the impact of financial risks on the performance of Islamic Banks in Malaysia for the period of 2008-2014. The study found a positive significant relationship between operational risk, capital risk, and banks' financial performance.

Moreover, Javid, Farooqi, Shoukat, and Rasheed (2020) studied the impact of financial risks on financial performance of conventional banks in Pakistan. The study found that credit risk had significant negative relationship with ROA and ROE. Meanwhile, the relationship between interest rate risk and performance was significantly positive. However, liquidity risk had insignificant impact on performance. However, the study used GLS which is difficult to interpret. In another study, Onsongo, Muathe, and Mwangi (2020) assessed the implications of financial risk on the performance of commercial and services companies. The study collected secondary data for the period 2013-2017. The study found that credit risk had an insignificant positive effect on ROE. Liquidity risk had a significantly negative effect on ROE whereas operational risk had a positive insignificant effect on ROE. 


\subsubsection{Liquidity Risks and Financial Performance}

A study by Mamatzakis and Bermpei (2017) focused on the influence of financial risks (liquidity and operational risks) on the growth of investment banks among the G7 and Switzerland banks. Using regression analysis, the study found a significant negative relationship between liquidity, operational risks and performance of the studied banks. However, the study was based on G7 and among the Switzerland banks. Wanjohi, Wanjohi, and Ndambiri (2017) assessed the effect of financial risk (liquidity risks and insolvency risks) on performance of insurance companies listed at Nairobi Securities Exchange. The correlation analysis found that liquidity risks and insolvency risks were negatively correlated to ROA which had statistically significant effect. However, reinsurance risk had positive correlation. Financial leverage and firm as measure of financial performance had a negative and positive statistical insignificant relationship with financial performance respectively.

Matayo and Muturi (2018) investigated the link between liquidity risk and operational risk and performance of Supermarkets in Nairobi County. Cost to income ratio was then used as an indicator to operational risk while liquidity ratio was used to proxy liquidity risk and ROA indicated financial performance. The study found that liquidity risk and operational risk had negative effect on ROA (measure for financial performance). Isiaka (2018) evaluated how liquidity risk, operational risks (financial risks proxies) affected insurance companies' performance of firms listed in Nigeria Securities Exchange. The study established that liquidity had a significant but negative effect on ROA while operational risk had positive relationship with ROA.

\subsubsection{Interest Rate Risks and Financial Performance}

Dey, Hossain, and Rezaee (2018) evaluated the extent financial risks (interest rate and foreign exchange risks) disclosure affected performance of manufacturing companies in Bangladesh. Through regression analysis, the study established that interest rate risks disclosure had a positive relationship with the firm performance as measured by leverage and firm size. Eneyew (2020) carried out a study on the effect of financial risks (interest rate risks, credit risk and liquidity risks) on profitability of commercial banks in Ethiopia. The population of the study was eight commercial banks for a period of 2000-2011. It was found that interest rate risk had positive significant relationship with profitability. The study found that the relationship between liquidity risks and credit risk was negative and statistically significant to profitability.

Matayo and Muturi (2018) investigated the link between interest risk, operational risk (financial risks) and performance of Supermarkets in Nairobi County. Through multiple regression, the study found that operational risk had negative effect on ROA which was used as a measure of financial performance. Muriithi (2016) research was based on assessing the relationship between financial risk and financial performance of commercials banks in Kenya. The study found that liquidity and credit risks (proxies of financial risks) had negative significant relationship with ROE. It was established that there was an inverse effect between financial risk and performance of Kenyan banks. Also, Wani and Ahmad (2017) carried out a study on liquidity risk, foreign exchange risk (financial risks) and performance of insurance industry in Indian. The study found that interest rate risk and liquidity risk had a positive statistical and significant relationship with return on asset. 


\subsubsection{Foreign Exchange Risks and Financial Performance}

Further, Patarai and MohamadFauzi (2016) studied the impact of financial risks on the performance of Islamic Banks in Malaysia. Secondary panel data was gathered for a period of 20 years, 1996-2015. The study used panel data regression model to run the estimation model and found a significant negative relationship between ROE and NPL ratio. It was also found that there was a significant negative relationship between the exchange ratio with ROA and ROE.

Panda and Leepsa (2017) investigated determinants of financial risks and firm performance in Japan for the period 2005-2011. The study found that firms with high leverage tend to perform worse than firms with low leverage. Basically, high leverage firms experienced worse performance during the crisis. Foreign exchange risk and operational risk were found to have positive relationship with financial performance. Moreover, Magondu (2016) studied the relationship between financial risks management and the performance of firms listed at the Nairobi Securities Exchange. The study found that there is a positive and significant correlation between credit risk and firm performance. The study also found that foreign exchange risk had negative relationship with performance.

Another study by Mwanja, Evusa, and Ndirangu (2018) investigated the effect of financial risks on performance of companies listed on the Nairobi Securities Exchange. The study found that foreign exchange risk was inversely related with ROA and ROE, an indication a negative relationship between independent and dependent variables. However, operational risk had positive relationship with performance. Odhiambo (2019) investigated effect of financial risk such as credit risks, interest rate risks, foreign exchange risk on the financial performance of commercial banks in Kenya. Diagnostic tests such as multicollinearity, normality, and heteroscedasticity were employed. The study found that interest rate risk had a significant positive effect on financial performance (firm size and leverage). On the other hand, foreign exchange risk and credit risk were established to have a significant but negative effect on performance.

\subsubsection{Firm Size and Financial Performance}

Patrick (2014) looked at the impact of financial risks on performance of Nigerian commercial banks. The study used firm size as intervening variable. The findings showed an insignificant negative impact of firm size as measured by total assets on financial performance. Wangalwa and Muturi (2018) sought to investigate operational risk and performance of Supermarkets in Nairobi County. The study found that operational risk negatively affected ROA while firm assets positively affected firm performance. However, the study focused on supermarkets rather than listed investment firms hence the need for the current study. The study also used operational risks while the current study uses foreign exchange risk, interest rate risks, and liquidity risk. 


\subsection{Research Methodology}

The study employed a descriptive research design. The design was chosen because it was able to provide a means to contextually understand and interpret financial risks and financial performance of investment firms listed at NSE. According to Bell, Bryman, and Harley (2018), a descriptive design helps in describing the existing conditions through interpretation and observation techniques. The target population of this study included all the five investment companies listed on the NSE. However, Kurwitu ventures limited was omitted in the course of data collection because it was listed towards the end of 2013. Secondary data covered a period of 8 years, 2011 to 2018. The current study used secondary data extracted from the published financial reports obtained from the websites of each of the investment firms. Secondary data was obtained from financial reports from each of the listed investment firms included; ROE, foreign exchange risk, interest rate risks, liquidity risks, and firm size. On dependent variable (financial performance), ROE (measure of financial performance) was computed by dividing annual profit after tax by total assets for each company (Arif \& Showket, 2019). Regarding independent variable (financial risks), foreign exchange risks (measure of financial risks) was operationalized by foreign exchange ratio that was computed by dividing foreign exchange gain by foreign exchange loss (Amin, Sanusi, Kusairi, \& Abdallah, 2018). Liquidity risks was measured by current ratio that was computed by current assets by current liabilities (Eneyew, 2020). Further, interest rate risks were measured by interest rate sensitivity gap ratio that was calculated by subtracting interest cost on liabilities from interest on assets and the results divided by total assets and outcome multiplied by $100 \%$ (Cuong, 2019; Mathuva, 2019). Moreover, firm size was proxied by total annual company assets and measured by the natural logarithm (ln) of total assets) (Valaskova, Kliestik, \& Kovacova, 2018). Statistical software known as Statistical Packages for Social Sciences (SPSS) version 20.0 was used for data analysis. The study analyzed data using descriptive statistics and regression analysis tests. To test the fitness of the regression model, diagnostic tests such as, multicollinearity, heteroscedasticity, and normality was used.

\section{The regression model:}

$Y_{i t}=\beta_{0}+\beta_{1} F_{i t}+\beta_{2} L_{i t}+\beta_{3} I R_{i t}+\beta_{4} F_{i t}+\varepsilon$

Where:

$\mathbf{Y}_{\mathbf{i t}}=$ Financial performance of firm $\mathrm{i}$ at time $\mathrm{t}$

$\boldsymbol{\beta}_{0}=\mathrm{a}$ constant

$\boldsymbol{\beta}_{\mathbf{1}}, \boldsymbol{\beta}_{2}, \boldsymbol{\beta}_{3}$, and $\boldsymbol{\beta}_{\mathbf{4}},=$ Beta coefficients of the independent variables

$\mathbf{F E}_{\mathbf{i t}}=$ Foreign exchange risk of firm $\mathrm{i}$ at time $\mathrm{t}$

$\mathbf{L R}_{\mathbf{i t}}=$ Liquidity risk of firm $\mathrm{i}$ at time $\mathrm{t}$

$\mathbf{I R}_{\mathbf{i t}}=$ Interest rate risk of firm $\mathrm{i}$ at time $\mathrm{t}$

$\mathbf{F S}_{\mathrm{it}}=$ Firm size of firm i at time $\mathrm{t}$

$\boldsymbol{\varepsilon}=$ Error term

$\mathbf{i}_{=}$firm 1 up to firm 8

$\mathbf{t}_{=}=$year 2011 up to year 2018 . 


\subsection{Findings and Discussion}

\subsection{Descriptive Statistics}

\section{Descriptive Statistics for Liquidity Risk}

The results for descriptive statistics for liquidity risks for all the investment companies were analyzed and presented in Table 1.

Table 1: Descriptive Statistics for Liquidity Risk

\begin{tabular}{lccccc}
\hline & N & Minimum & Maximum & Mean & Std. Deviation \\
\hline Centum & 8 & .35 & .85 & .6445 & .15314 \\
Olympia & 8 & 1.12 & 4.10 & 2.4885 & 1.02673 \\
Trans century & 8 & .20 & 1.28 & .7815 & .42867 \\
Home Afrika & 8 & .07 & 1.19 & .7089 & .30304 \\
$\begin{array}{l}\text { Valid N } \\
\text { (listwise) }\end{array}$ & 8 & & & & \\
\hline The results in Table 1 shows that the minimum liquidity for Centum in the 8-year period was 0.35
\end{tabular}

The results in Table 1 shows that the minimum liquidity for Centum in the 8 -year period was 0.35 while the maximum was 0.85 . The mean was 0.6445 with a standard deviation of 0.153 that shows a small variability in liquidity risk over the period. Olympia had a mean of 2.49 with a standard deviation of 1.027 indicating a moderate variability in liquidity risks. The minimum and maximum for Olympia was 1.12 and 4.10 respectively. The results also show that Transcentury had a liquidity risk mean of 0.782 with a standard deviation of 0.429 which indicates a small variability in liquidity risks over time. The results could be interpreted to mean that all the investment firms listed on the NSE are well managed an indication that they are adhering to NSE financial guidelines.

\section{Descriptive Statistics for Foreign Exchange Risk}

The descriptive statistics results for foreign exchange risk for all the investment companies listed at the NSE were also analyzed and presented in Table 2.

Table 2: Descriptive Statistics for Foreign Exchange Risk

\begin{tabular}{lccccc}
\hline & N & Minimum & Maximum & Mean & Std. Deviation \\
\hline Centum & 8 & 2.34 & 46.54 & 18.6831 & 14.88196 \\
Olympia & 8 & -.46 & 23.45 & 4.3068 & 7.82572 \\
Transcenury & 8 & .98 & 6.43 & 2.9975 & 1.90665 \\
Home Afrika & 8 & .66 & 6.74 & 3.0475 & 1.96178 \\
Valid N (listwise) & 8 & & & & \\
& & & & & \\
\hline
\end{tabular}


As presented in table 2, Centum limited had a mean score of 18.68 with a standard deviation of 14.88 showing a large variability for foreign exchange risks over the time. The minimum and maximum score for same firm was 2.34 and 46.54 respectively. The study established that Olympia limited had a means score of 4.31 and the standard deviation was 7.83 , an indication that the exchange risk had a large variability over the time. The minimum and maximum scores for foreign exchange risk was -0.46 and 23.45 , respectively. From the results, it is clear that all firms managed well their foreign exchange risks except Olympia limited that had a negative foreign exchange risk in one of the years (2015).

\section{Descriptive Statistics for Interest Rate Risks}

The section presents the descriptive statistics results for the interest rate risks for all the companies for the year 2011 to 2018. The results are shown in Table 3.

Table 3: Descriptive Statistics for Interest Rate Risks

\begin{tabular}{lccccc} 
& N & Minimum & Maximum & Mean & Std. Deviation \\
\hline Centum & 8 & -34 & 43 & 15.50 & 22.947 \\
Olympia & 8 & 9 & 54 & 29.00 & 15.362 \\
Transcentury & 8 & -43 & 76 & 26.00 & 34.059 \\
Home Afrika & 8 & -41 & 54 & 25.75 & 31.436 \\
Valid N (listwise) & 8 & & & &
\end{tabular}

The results shown in Table 3 indicate that all the companies poorly managed their interest risk over some years except Olympia limited that effectively managed its interest rate risks over the 8year period. However, Centum had a mean of 15.50 with a standard deviation of 22.947 indicated large variability for interest rate risks over the period while Olympia had a mean of 29.00 with a standard deviation of 15.362. Essentially, all the companies had a large variability of interest rate risks over the time.

\section{Descriptive Statistics for Firm Size (Natural logarithm (Ln))}

The study used firm size as measured by natural logarithm (Ln). The descriptive results for all the companies are presented and interpreted in Table 4.

Table 4: Descriptive Statistics for Firm Size (Natural logarithm (Ln))

\begin{tabular}{lccccc}
\hline & N & Minimum & Maximum & Mean & Std. Deviation \\
\hline Centum & 8 & 7.18 & 7.52 & 7.3431 & .14271 \\
Olympia & 8 & 6.83 & 7.96 & 7.6945 & .37964 \\
Transcentury & 8 & 7.11 & 10.34 & 7.6305 & 1.09623 \\
Home Afrika & 8 & 7.50 & 7.82 & 7.6774 & .09363 \\
Valid N (listwise) & 8 & & & &
\end{tabular}

According to the results shown in Table 4, the total mean for firm size as measured by natural logarithm was 7.34 with a standard deviation of 0.143 ; meaning that there was small variability of 
firm size over the period. The minimum and maximum for firm size was 7.18 and 7.52 respectively. Further, Olympia limited had a mean of 7.69 and deviated at 0.38 ; meaning firm size had a small variability over the period of the study. However, Olympia had the highest firm size, followed by Home Afrika, Transcentury, and Centum in that order.

\section{Descriptive Statistics for Financial Performance (ROE)}

The study also conducted a descriptive statistics test for financial performance for all the companies. The results are indicated in Table 5.

Table 5: Descriptive Statistics for Financial Performance (ROE)

\begin{tabular}{lccccc}
\hline & N & Minimum & Maximum & Mean & Std. Deviation \\
\hline Centum & 8 & .04 & .17 & .1081 & .05433 \\
Olympia & 8 & .02 & .04 & .0279 & .00596 \\
Transcentury & 8 & .03 & .37 & .1590 & .11276 \\
Home Afrika & 8 & -2.31 & 4.05 & 2.0825 & 2.13180 \\
Valid N (listwise) & 8 & & & &
\end{tabular}

The results in Table 5 indicate that Centum had a mean of 0.108 for ROE with a standard deviation of 0.054 indicating a small variability for ROE over the years. The minimum and maximum scores for the same company was 0.04 and 0.17 respectively. Further, the mean for Olympia over the years was 0.028 and the standard deviation was 0.006 indicating a very small variability for ROE over time. However, Home Afrika had a negative minimum ROE of -2.31 indicating that the company performance was below average in 2011 hence the negative ROE score.

\subsection{Diagnostic tests.}

Some of the diagnostic tests conducted include Normality, Multicollinearity, and Heteroscedasticity

Table 6: Tests for Normality, Multicollinearity, and Heteroscedasticity

\begin{tabular}{lcccc}
\hline & Normality & Multicollinearity & \multicolumn{2}{c}{ Heteroscedasticity } \\
Variables & Sig. & VIF & t & Sig \\
\hline ROE & 0.345 & & & \\
Liquidity risks & 0.123 & 2.014 & 0.014 & 0.531 \\
$\begin{array}{l}\text { Foreign } \\
\text { exchange risk }\end{array}$ & 0.116 & 4.207 & 0.104 & 0.317 \\
$\begin{array}{l}\text { Interest rate } \\
\text { risk }\end{array}$ & 0.109 & 2.027 & 0.343 & 0.611 \\
Firm size (Ln) & 0.454 & 3.008 & 0.521 & 0.401 \\
\hline
\end{tabular}


The results for various diagnostic were presented in table 6. For normality test, the study used Shapiro Wilk test of normality to assess the normal distribution of data. The null hypothesis was that data was not normality distributed. Since the p-values for all the variables $(\mathrm{ROE}=0.345$, Liquidity $=0.123$, Foreign exchange risk $=4.207$, Interest rate risk $=0.109$, and Firm size $=0.454$ ) are $>0.05$, the null hypothesis is rejected; therefore, data is normally distributed.

The study used VIF to test the null hypothesis of multicollinearity. The results show that all the variables have their VIF less than 10 and more than 1 thumb rule. For instance, liquidity risks, foreign exchange rate risks, interest rate risk, and firm size had VIFs of 2.014, 4.207, 2.027, and 3.008 , respectively. The null hypothesis is, therefore, multicollinearity is absent.

Regarding heteroscedasticity, the null hypothesis should be rejected if the p-values for the variables are $<0.05$. However, if the p-values $>0.05$, the null hypothesis of heteroscedasticity will not be rejected. The study found that liquidity risks, foreign exchange risk, interest rate risk, and firm size had p-values of $0.531,0.317,0.611$, and 0.402 , respectively. Given that all the variables had p-values $>0.05$, heteroscedasticity not present; meaning that the requirement for constant variance was not violated.

\subsection{Regression Analysis}

The results are shown in Table 7.

Table 7: Regression Analysis

\begin{tabular}{lcccc}
\hline \multicolumn{5}{c}{ Dependent variable $=$ Firm performance (ROE) } \\
\hline Variables & $\begin{array}{c}\text { Standardized } \\
\text { Coefficient } \\
\text { (Beta) }\end{array}$ & Standard errors & t-value & p-value \\
\hline Constant & 1.216 & 4.642 & .262 & .906 \\
Liquidity risk & -.017 & .034 & -.082 & .079 \\
Exchange rate risk & -.055 & .368 & -.269 & .038 \\
Interest rate risk & -.072 & .013 & -.877 & .035 \\
Firm size (Ln) & .091 & .611 & .450 & .050 \\
Model summary: & & & & \\
R & $.191^{\mathrm{a}}$ & & & \\
R square & .036 & & & \\
ANOVA: & & & \\
F-statistic (p-value) & $\mathrm{N}=32$ & & \\
& & & \\
\hline a $=$ Constant; ${ }^{\mathrm{b}}=$ Coefficients of each variable. & & \\
Significance level = 0.05 & & &
\end{tabular}

The results in Table 7, shows that the regression model is good fit as was explained by $\mathrm{R}$ of $0.191 \%$. Therefore, there is a variation of $19.1 \%$ in the financial performance of listed investment firms. The result for ANOVA indicate that the model is reliable because it is significant at the 5\% level ( $p$-value $=0.049)$. In agreement, Wani and Ahmad (2018) that found that variables such as liquidity, operational risk, credit risk, foreign exchange risk, solvency risk, and interest rate risk correctly predicted the financial performance of banks in India. The results also concur with 
another study by Javid et al. (2020) that established that the variation in financial performance was suitably explained by creditrisk, interest rate risk, and liquidity risk as was showed by a correlation coefficient (R) of $23.78 \%$.

Regarding the coefficient results, the study found that liquidity risk was not statistically significant but was negatively related with financial performance $(\beta=-0.017$, $p$-value $=0.079)$. The results imply that a reduction in liquidity risk could lead to increased financial performance of investment firms. The results resonate with another study by Cuong (2019) that found that liquidity risk had a negative effect on financial performance. On the contrary, a study by Patarai and Mohamad (2016) found not statistical significant relationship with financial performance.

The study also found that foreign exchange risk had significant but negative relationship with financial with financial performance $(\beta=-0.055$, $\mathrm{p}$-value $=0.038)$ at the $5 \%$ level. This means that a decrease in foreign exchange risk results to increase in financial performance of listed investment firms. In agreement, a study by Onsongo, Muathe, and Mwangi (2020) found a negative significant relationship between foreign exchange risks and financial performance (ROA and ROE). However, the results contradict a study by Panda and Leepsa (2017) that found that foreign exchange risk had positive significant relationship with financial performance.

Further, interest rate risk was found to have a negative but statistically significant relationship with financial performance $(\beta=-0.072, \mathrm{p}$-value $=0.035)$ at the $5 \%$ level. This could be interpreted to mean that reduced interest rate risk results into an increase in the financial performance of investment firms. The results are inconsistent with a study by Javid et al. (2020) that found that the relationship between interest rate risk and performance was significantly positive. Similarly, a study by Wani and Ahmad (2017) found that interest rate risk had a positive statistical and significant relationship with return on asset

It was found that firm size as measured by natural logarithm had positive and statistical significant relationship with financial performance $(\beta=0.091$, p-value $=0.050)$ at the $5 \%$ level. This is an indication that increased firm size by 0.091 percent could lead to increased financial performance of investment firms listed at the NSE. The results support another study by Wangalwa and Muturi (2018) that found that firm size (Ln) was positively and significantly related with firm performance. However, the results contradict a study by Odhiambo (2019) that found that firm size had insignificant and negative relationship with financial performance as measured by ROA.

\subsection{Conclusions}

The study concludes that a decrease in liquidity risk results to increased financial performance. Therefore, having cash in excess and failing to invest with the available cash could consequently make lose investment opportunity that can bring more revenue and this exposes firms to financial risks.

The study also concludes that a decrease in foreign exchange risk exposure could lead to improved financial performance. Therefore, firms' exposure to foreign currency exchange rate adversely affect the financial performance of the firms thus exposing them to financial risks.

Interest rate risk was found to have negative and significant relationship with financial performance. Therefore, a decrease in the interest rate risk could increase financial performance of investment firms. 
The study concludes that firm size had a positive and significant relationship with financial performance as measured by ROE. Thus, the more the firms increase their total assets, the more they are able to obtain improved financial performance thus reducing exposure to financial risks.

\subsection{Recommendations}

The study recommends that the government through its regulatory agencies should ensure they pay attention to the listed investment firms that are struggling to conform to the minimum financial requirements including liquidity. The listed investment firms should also increase the current ratio to minimize exposure to financial risks. Further, investment firms should make sure they invest their idle of cash so as to diversify investment portfolio.

The study recommends that the management of investment firms should introduce a robust efficient and effective strategies that can assess, identify and also manage foreign exchange risks to improve financial performance. Based on the risk assessment results, the finance managers can exert more effort in the strategies that can help in the management of exchange rate risk to reduce its negative impact on the financial performance. Further, investment firms can also use various financial derivatives to reduce the effect of exchange rate risk.

Further, the study recommends that investment firms listed at the NSE can explore various means they can use to improve capacities so as to manage interest rate risks exposure. For instance, interest rate risks can be mitigated by using financial derivatives and also through securitization of assets to minimize interest rate risks. 


\section{References}

Amin, M. A. M., Sanusi, N. A., Kusairi, S., \& Abdallah, Z. M. (2018). Inverse relationship of financial risk and performance in commercial banks in Tanzania. Investment Management and Financial Innovations, 11(4), 279-291

Arif, A. \& Showket, A. (2019). Relationship between financial risk and financial performance: An Insight of Indian Insurance Industry. International Journal of Science and Research, 4(11), 1424-1433.

Asensio, A. (2017). Insights on endogenous money and the liquidity preference theory of interest. Journal of Post Keynesian Economics, 40(3), 327-348.

Bell, E., Bryman, A., \& Harley, B. (2018). Business research methods. Oxford university press.

Chipa, T., \& Wamiori, Y. (2020). Financial risk and the financial performance in listed commercial and investment banks in Kenya. International Journal of Innovation, Creativity and Change, 13(12), 160-180.

Cuong, D. X. (2019). Evaluated the extent financial risk disclosure affected performance of manufacturing companies in Bangladesh. International Journal of Financial Research, 6(4), 123.

Dey, R. K., Hossain, S. Z., \& Rezaee, Z. (2018). Financial risk disclosure and financial attributes among publicly traded manufacturing companies: Evidence from Bangladesh. Journal of Risk and Financial Management, 11(3), 50.

Disatnik, D., \& Sivan, L. (2016). The multicollinearity illusion in moderated regression analysis. Marketing Letters, 27(2), 403-408.

Eneyew E. A. (2020). Financial risks affecting profitability of commercial banks in Ethiopia. International Journal of Research and Analytical Reviews, 6(1), 881-891.

Halunga, A. G., Orme, C. D., \& Yamagata, T. (2017). A heteroskedasticity robust Breusch-Pagan test for Contemporaneous correlation in dynamic panel data models. Journal of econometrics, 198(2), 209-230.

Isiaka, L. O. (2018). Effect of liquidity risk, premium growth on the performance of quoted insurance firms in Nigeria: A panel data analysis. American Finance \& Banking Review, 2(1), 40-89.

James, N., \& Kepha, O. (2020). Effects of risk management practices on the performance of insurance firms in Kenya: A case of AIG insurance company limited. International Journal of Finance and Banking Research, 210, 122-128.

Javid, S., Farooqi, M. R., Shoukat, A., \& Rasheed, A. (2020). Assessment of financial risks on financial performance of conventional banks: An empirical evidence from Pakistan. Paradigms, 2(SI), 81-87.

Jensen, M. C., \& Meckling, W. H. (1976). Theory of the firm: Managerial behavior, agency costs and ownership structure. Journal of Financial Economics, 3(4), 305-360. 
Le, C. H. A., Shan, Y., \& Taylor, S. (2020). Executive compensation and financial performance measures: Evidence from significant financial institutions. Australian Accounting Review, 30(3), 159-177.

Magondu, A. M. (2016). Extreme risk and the performance of firms listed in the Nairobi Securities Exchange. International Journal of Financial Studies, 9(8), 616-620.

Mamatzakis, E., \& Bermpei, T. (2017). The influence of financial risks on the growth of investment banks in Switzerland. International Review of Financial Analysis, 35, 102-117.

Matayo, W., \& Muturi, W. (2018). Effect of financial risk on financial performance of large-scale supermarkets in Nairobi County, Kenya. International Journal of Social Sciences and Information Technology, 4(10), 574-591.

Mathuva, D. M. (2019). Investigated the effect of operational risk on performance of commercial banks in Kenya: The Kenyan Scenario. The International Journal of Applied Economics and Finance, 3(2), 35-47.

Mirie, M. (2018). Determinants of financial performance in general insurance companies in Kenya. European Scientific Journal, 11(1), 288-297.

Mishra, P., Pandey, C. M., Singh, U., Gupta, A., Sahu, C., \& Keshri, A. (2019). Descriptive statistics and normality tests for statistical data. Annals of cardiac anaesthesia, 22(1), 67.

Muinde A. M. (2018). The effect of financial risk on performance of insurance companies listed at Nairobi Securities Exchange. International Journal of Financial Studies, 6(7), 66-71.

Muriithi, J. G. (2016). Effect of financial risk on financial performance of commercial banks in Kenya. International Journal of Financial Studies, 4(5), 88-91.

Mwanja, S. K., Evusa, Z., \& Ndirangu, A. W. (2018). Influence of financial risk on firm performance among companies listed on the Nairobi Securities Exchange. International Journal of Applied Economics, Finance and Accounting, 3(2), 56-63.

Odhiambo, O. N. (2019). Financial risks and financial performance of commercial banks in Kenya. International Journal of Financial Studies, 6(7), 107-111.

Onsongo, S. K., Muathe, S., \& Mwangi, L. W. (2020). Financial risk and financial performance: evidence and insights from commercial and services listed companies in Nairobi securities exchange, Kenya. International Journal of Financial Studies, 8(3), 51.

Panda, B., \& Leepsa, N. M. (2017). Agency theory: Review of theory and evidence on problems and perspectives. Indian Journal of Corporate Governance, 10(1), 74-95.

Patarai, M. A. A., \& MohamadFauzi, N. F. (2016). The impact of financial risks on the performance of Islamic Banks in Malaysia. Journal of Retailing and Consumer Services, 32, 189-197

Patrick, R. H. (2021). Durbin-Wu-Hausman Specification Tests. In handbook of financial econometrics, mathematics, statistics, and machine learning (pp. 1075-1108).

Plonsky, L., \& Oswald, F. L. (2017). Multiple regression as a flexible alternative to ANOVA in L2 research. Studies in Second Language Acquisition, 39(3), 579-592. 
Sisay, D. (2017). The effect of financial risk on performance of insurance companies in Ethiopia. College of Business and Economics, 1-120.

Valaskova, K., Kliestik, T., \& Kovacova, M. (2018). Management of financial risks in Slovak enterprises using regression analysis. Oeconomia Copernicana, 9(1), 105-121.

Wang, Z., \& Sarkis, J. (2017). Corporate social responsibility governance, outcomes, and financial performance. Journal of Cleaner Production, 162, 1607-1616.

Wani, A. A., \& Ahmad, S. (2018). Relationship between financial risk and financial performance: An insight of Indian insurance industry.

Wani, A., \& Ahmed, Y. (2017). The relationship between liquidity risk and performance of insurance industry in Indian. European Financial Management Association, 44, 1-5.

Wanjohi, S. M., Wanjohi, J. G., \& Ndambiri, J. M. (2017). Influence of financial risk on the performance of insurance companies listed at Nairobi Securities Exchanges in Kenya. International Journal of Finance and Banking Research, 3(5), 70-81. 